\title{
Digital Entrepreneurship via Sustainable Online Communication of Dentistry Profession, Oradea, Romania: A Longitudinal Analysis
}

\author{
Felicia Constantin ${ }^{1, *}$ and Androniki Kavoura ${ }^{2}$ (D) \\ 1 Faculty of Economic Sciences, University of Oradea, Str. Universitatii 1, 410087 Oradea, Romania \\ 2 School of Administrative, Economics and Social Sciences, University of West Attica, \\ 250 Petrou Ralli and Thivon, 12244 Aigaleo, Greece; nkavoura@uniwa.gr \\ * Correspondence: fconstantin@uoradea.ro
}

check for updates

Citation: Constantin, F.; Kavoura, A. Digital Entrepreneurship via Sustainable Online Communication of Dentistry Profession, Oradea, Romania: A Longitudinal Analysis. Sustainability 2022, 14, 802. https:/ / doi.org/10.3390/su14020802

Academic Editor: Roberto Cerchione

Received: 9 November 2021

Accepted: 5 January 2022

Published: 11 January 2022

Publisher's Note: MDPI stays neutral with regard to jurisdictional claims in published maps and institutional affiliations.

Copyright: (C) 2022 by the authors. Licensee MDPI, Basel, Switzerland. This article is an open access article distributed under the terms and conditions of the Creative Commons Attribution (CC BY) license (https:// creativecommons.org/licenses/by/ $4.0 /)$.

\begin{abstract}
Dentistry is an entrepreneurially oriented public interest profession that must maintain a balance between professional specificity and business sustainability. Communicating with patients is vital in a competitive system, and the dentist needs to use handy resources such as websites and social media. The aim of this research is (a) to examine whether websites and social networks are a digital entrepreneurship tool used in the dentistry profession in Oradea, a city in full economic development in Romania, to promote the profession nationally and internationally, (b) to compare the changes made using digital tools in the period between 2018-2021 for all licensed dentists in the mentioned city (between 430-450 people, depending on the stage of analysis) using the content analysis method and (c) to identify how the lockdown period imposed by the emergence of the COVID-19 pandemic influenced not only the sustainability of the medical services provided to the population but also the communication practices of the dental offices. The results of examining the dentist's online presence reveal that there is an interest among practitioners to grow their business sustainably through a digital presence that is increasingly relevant to them and their clients, but the potential remains under-exploited.
\end{abstract}

Keywords: entrepreneurship; communication; COVID; websites; Facebook

\section{Introduction}

Using a broad range of web tools is crucial for entrepreneurs in their effort to attain better performance. Dentistry is among entrepreneur-like occupations [1]. Dentists consequently adopt the characteristics of a business person due to market mechanisms that lead to the loss of their professional autonomy [2]. The National Institute of Dental and Craniofacial Research (NIDCR) recommends the inclusion of management skills, entrepreneurship and technology transfer in dental education [3]. Apart from medical issues that dentists need to take into consideration, various duties are also associated with running the business, e.g., promoting the business, bringing new customers and scheduling all operational tasks [4]. Garcia and Campos (2020) [5] consider that micro and small businesses, such as dental clinics, need an efficient management system in order to survive in today's business world and to play a role in a country's economy. The dental practice must be managed as a business and must use the most efficient tools (e.g., sensory dental branding) which can affect both the quality management of the dental office and the expectations of the patient [6].

Communication tools need to be used by the entrepreneurs to make known to the public the high quality of their services. Dental care professionals are continuously using social media to share, promote and advertise their practice, complying with various ethical rules $[7,8]$. Social media usage has not been systematically and successfully implemented by medical professionals yet. Studies in different countries illustrate that health care professionals use social media tools for personal activities, whereas a small percentage use 
these facilities for professional reasons and as a marketing tool $[9,10]$. Research on patients' testimonials illustrated they used the Internet in order to solve various dental issues [11,12], which shows the necessity for professionals to adopt various web tools to communicate with the public. Because of the lack of a clear understanding of the dentists about the usefulness of communication, we need further research to be conducted $[7,8,13,14]$ in order to measure its use. Considering the fact that there is still a lack of publicly available information in this domain, family, friends and acquaintances remain the major source of information when a person needs advice about doctors and practices [12].

Using online tools to promote the business' offerings also creates new opportunities in medical tourism, because it allows patients to take advantage of quality and inexpensive health services. The continuously developing medical tourism creates poles of medical services which generate patient and income flows in many countries from Asia, Latin America, and Europe; it favors also a global flow of medical professionals across international borders [15]. Various web tools help health practitioners to share and promote healthy behaviors, engaging in that way with the public and providing them with information [9]. Despite this, medical tourism marketing is not fully using the potential of interactive communication through social media and other online platforms [16].

Nambisan (2017) [17] argues that the specialists may decrease the uncertainty that exists in entrepreneurial activities with implementing new digital technologies (web tools as well as local applications). It could mean extra costs but also the advantage of, e.g., flexible time appointment for the clients which in return is facilitating a direct clientdentist relationship. We can conclude that medical apps providing relevant information for practitioners and patients could have a positive impact in dentistry [18].

Based on 2019 statistics about social media, the Internet has 4.54 billion users, of which 3.725 billion are active social media users (users of such platforms grew by 328 million between October 2018 and October 2019) [19]. The COVID-19 pandemic has also emphasized the need to employ new technologies, such as teleworking globally and across different sectors. As of 5 June 2020, a technical note by the International Labor Organization measuring remote work, telework, work at home and home-based work established the need to implement proper technologies [20].

This research aims to extend our knowledge on dentists' practices regarding online communication to promote their profession, taking Oradea, Romania as a case study.

The crisis created by the pandemic in the early months of 2020 revealed the need to assign a new role to communication with patients, through various web tools.

\section{Some Aspects of Sustainability and Regulation in Dentistry}

\subsection{Sustainability and Digital Transformation in Dentistry with Implementation of Social Media}

By adopting 2030 Agenda for Sustainable Development, The United Nations took a historic decision on a "comprehensive, far-reaching and people-centered set of universal and transformative" Sustainable Development Goals [21]. On the base of this engagement, the World Dental Federation has adopted in 2017 a statement dealing with the Sustainability in Dentistry. According to this document, oral health professionals are preoccupied with working together in the interests of sustainability, considering oral health as an essential part of human life; in this way, the profession of dentistry should integrate sustainable development goals into daily practice [22].

The health and welfare of populations depends on the access of all people to health services and to essential information, meaning the communication of good oral-health habits.

If 10 years ago the profession remained "pretty vague" about the significance and the importance of sustainable medicine [23], today the evolution is clear. Embedding sustainability into clinical care involves a set of methods and resources in which medical education practitioners and trainers must take part together [24].

In this sense, for Wolf and Campus (2021) [25] the profession acknowledges the change and the progress in such new fields as artificial intelligence, big data, sustainability, green dentistry, tele-dentistry, cross-border use of services and digital transformation in health care. 
Considering recent studies in sustainability and circular economy in the health industry conducted by World Health Organization (2018) [26] and other researchers [27,28], we find that the transition to the circular economy favors the emergence of new business models capable of achieving sustainable development goals.

In this way the growth of medical tourism markets could also be helped, offering some models of sustainability in a large sense [29]. But we should not ignore that all these entrepreneurial opportunities involve several ethical considerations and bioethical limits [30].

Sustainability in dentistry is a complex concept, and refers to three dimensions: economic, social and environmental [21,22].

A large literature review conducted by Martin et al. (2021, 2021) and funded by the World Dental Federation found that dental professionals have little knowledge and awareness of the environmental sustainability aspects of their practice. The inventory of recommendations and examples of environmentally sustainable practices are important resources for the profession, but their implementation faces several barriers. One of these, according to the authors, is a "perceived disengagement" between citizenship responsibility and the responsibility of professional activities [31,32].

In our opinion, the prioritization of professional activities is closely linked to the concern for the economic sustainability of their business.

We consider economic sustainability as an essential component of an activity, because without it, we cannot speak of disposable resources for implementing environmental or social sustainability practices. Before addressing issues such as environmental impacts, materials, recycling, biomedical waste management, policy and guidelines, research or education (inventoried and recommended by the FDI-funded team), dentists need to ensure the financial sustainability of their business, especially if they do not benefit from active governmental support.

Communication strategy is an essential part of implementing sound economic sustainability. It is the tool through which the business seeks, finds, attracts, persuades and keeps patients. Dentists who take care of this aspect maximize their impact on the market and strengthen their reputation. Constant development of the communication strategy allows the entrepreneur to increase their revenue and profit.

Duane et al. (2019) indicate better communication as the 4th of their 10 tips for sustainable dentistry. They point out that the practitioner can convey a vision that promotes sustainability on the practice website or social media platforms [33].

Using tools such as a website or a social media platform allows the fulfilment of businesses' social responsibility, through publishing materials regarding health education as well as critical information in case of emergency or calamity. It thus contributes to the well-being of populations and the worldwide access for all people to health services and to and healthy life.

Bakaeen et al. (2021) [34] consider that dentists need a robust business plan in order to address the sustainability of their practices. The entrepreneurial role of dentists pushes them to consider the business side of the dental practice, in particular the importance of quality, creativity and innovation, alongside the importance of meeting the needs of patients in order to survive in an increasingly competitive environment [35]. Price information, available services and promotions are advisable to make public since they attract the target market. Owners of dental practices are entrepreneurs but often lack comprehensive business knowledge [36].

The dental office should be seen as a company, and consequently it should have-in its planning part of the budget - a line aimed at attracting and keeping customers [37]. It could invest this money in order to be viable, for using communication channels in the digital media in order to approach clients and to develop and maintain a relationship with them.

The researchers associate entrepreneurship in the dental industry with the ability to use innovative marketing activities in line with the actual codes of ethics in order to deal with competition. Examined dental practices in Hungary illustrated that the use 
of marketing activities differs from professional to professional and depends on their knowledge and awareness [38]. Dentists have user accounts for their dental practices on various social media platforms because it is a relatively convenient and inexpensive means of communication, by which they can conduct marketing activities and provide dental health information [14]. The necessity of applications with commercial elements in healthcare and the shift towards the commodification of dental services brings forth whether dentistry is a business that needs to adhere to codes regarding patient-professional relationships [39].

According to Kapoor et al. (2018) [40] and Aichner et al. (2021) [41], social media's definition knows a critical evolution, depending on the period, research field, or scientific background. We consider social media as defined by Anderson and Hardin (2018) [42] and we understand it on online websites that allow individuals to communicate and establish social networks such as Facebook. Parmar et al. (2018) [14] observed that even the role of social media in dental services remains vague, and an active social media presence enhances patient interaction and engagement. Directed campaigns for dentists could optimize the use of social media for both professional and personal purposes [43]. Other studies investigated the relationship between the gender of the patients and their usage habits of social media in the selection of a clinic; but, as noted by Alkadhi et al. (2020) [44], not much literature exists to assess the influence of social media on the outcome of patients' preferences regarding a dental clinic.

The dental office, seen as an entrepreneurial initiative, could suffer the consequences of an extraordinary situation, such as a pandemic. In this situation, the dental practice seen as a business must adapt its offer and its messages to external constraints while respecting its role as a provider of public health services. It is difficult to maintain sustainability when taking into consideration the economic repercussions and losses incurred by the sector in a period of crisis, as the COVID-19 pandemic [45], when the modification of the services and the obligation to close practices have created uncertainty [46].

The paper provides a framework that allows us to examine some digital marketing strategies used in dentistry. It quantifies the qualitative and quantitative evolution over time of the major tools used in digital communication by dentists.

We have studied the quantitative and qualitative evolution of their websites and the number and category of their Facebook profiles. In order to be as precise as possible in evaluating the websites, we have chosen 42 unique items grouped into six categories of information. We appreciate that our work can be useful for the professional community and the researchers in the medical or economic field, because it summarizes the dynamics of the communication strategies.

\subsection{Regulation and Professional Conduct on Online Activities from Dentists}

Health care professionals who employ web tools for their promotional activities need to take into consideration the risk of being exposed to a variety of breaches of professional conduct [8,47] or patients' confidentiality [48]. Published guidelines on how medical professionals interact with patients through web tools are rather universal and, thus, may not provide always workable solutions [14]. Users of such tools within a health care context find it challenging to employ them fully because of ethical dilemmas and privacy concerns [49]. Regulation issues may create an obstacle for communications using the Internet by healthcare practitioners. Studies found few websites associated with health issues fully conform to all the regulations, and very few incorporate all the expert advice on website content [50].

The EU Manual of Dental Practice [51] mentions the tremendous variation across the EU/EEA regarding advertising practices allowed to be applied by dentists and their practice. The document notes that virtually all countries permit the use of dental practice websites, with some isolated exceptions. Despite this permission, in some countries, stringent regulations are in effect regarding the creation of a website or the use of social media. The Manual includes also in Annex the CED's Code of Ethics related to the 
Directive on Electronic Commerce and the regulations in European countries concerning the mandatory and the discretionary information.

Until 2019 in France, the National Order of Dentists officially required the respect of two very restrictive charters related to advertising and information published in the media (dated 2014) [52] and referring to the professional websites of practitioners (dated 2015) [53].

However, social and technological developments, the proposals of the European Council of State, European case law and other regulations which were adopted in other European Union countries have led to new and more permissive regulations.

In 2018, a complex document elaborated by the French Council of State [54] established the new rules applicable to health professionals regarding information and advertising. The rapid growth of the digital economy undermined some restrictions. Adopted in 2019, a new Chart [55] opens a new era because the law grants greater freedom of communication to the dentist, evidently within the framework of ethics and with the practitioner's responsibility. Significant reform concerned the enrichment of possibilities in digital communication, in particular on the practitioner's website and all the media. In the same manner as previous ones, this document also emphasizes the respect for the deontology and the principle of not seeing the dental profession as a profit-oriented business.

In the United Kingdom, the General Dental Council (GDC) establishes the standards that regulate dental practices. Dentists may use sound business methods to ensure the profitability of their business. These methods must respect the ethical rules of the profession. The GDC guides the use of social networking, advertising or marketing websites for all practitioners [56].

In Belgium, the Dental Advertising Law of 1958 (Dental Advertising Law, 1958) which prohibited all advertising was respected until the justice repealed it in 2018 [57] after a long legal debate and in harmonization with the European Directive "that obliges Member States to ensure that members of regulated professions may use commercial communications online, subject to compliance with professional rules" [58].

In Romania, the Code of Medical Ethics (2016) [59] and the Code of Ethics for Dentists (2010) [60] regulated and established the limits for the professional situation. This last code forbids the usage of advertising of any kind, letting the dentist's reputation be based only on competence and dignity and prohibiting the practice of dentistry as a commercial activity. According to the same document, the information on one's website must meet the criteria of being factual and easily verifiable, and the practitioner must ensure that the information is not misleading or comparative.

However, since competition is high and they operate in a free market economy, dentists employ communication tools for promotional strategy. In addition, it is necessary to consider the fact that the Romanian State subsidizes an insignificant part of the dental procedures, which constrains dentists to put in place strategies that make their practices profitable. Further harmonization of the Romanian legislation was necessary, in line with other European countries. The new Code of Ethics for Dentists, adopted in August 2021 [61], establishes the same professional principles, but is much more detailed and contains some precise regulations. As far as websites are concerned, they must abide by the same ethical rules, being created and updated under the supervision of the practitioner. An additional element in this code is the regulation regarding the use of social networking in a responsible and civilized manner.

\section{Methodological Considerations: Background Research-Oradea, Romania and the Lockdown Period}

The aim of this research is to examine which web tools are used in digital entrepreneurship by the members of the dentistry profession in Oradea, in order to promote their services nationally and internationally. Oradea, the main city of Bihor County, with a population of over 220,000 inhabitants [62] is a well-known multiethnic, multicultural and multilingual city in 
Romania. The interest of the average dentist in Bihor County is to work in Oradea, where the population has more financial resources available for dental treatment.

For this purpose, we compared the variations in the usage of digital tools in the period between 2018-2021 for all licensed dentists in the mentioned city. We have paid special attention to the year 2020, in order to identify how the lockdown period imposed by the emergence of the COVID-19 pandemic influenced the sustainability of the medical services provided to the population.

We employed in our research content analysis, which determines the specification of categories focusing on what can be seen and counted [63].

This is a longitudinal study, which followed a complete professional body in the same geographical and administrative space. Between 430-450 people (depending on the stage of analysis) were analyzed individually, regarding their having a website, Facebook account or both, in the years 2018 and 2021.

The research was conducted by considering the dentists officially authorized to practice dentistry. The information regarding licensed dentists is publicly available on the website of the Territorial College of Physicians Dentists of Bihor [64], which is updated annually. Since the lists provided officially include all the authorizations granted to every dentist (sometimes, one person can hold multiple authorizations) the authors of the research selected for analysis only the unique dentists in Oradea.

Using search engines, we searched those websites and Facebook profiles that belong to licensed dentists who were present in the official list of the local College. After inventorying all our findings, we registered all unique websites and profiles of the doctors. The resulting website findings belong either to individual practices (where only one doctor or members of the same family work), or to clinics, where more than one doctor works. For example, of the 39 websites identified in 2021,56.5\% belong to practices comprising one or two doctors, $33.3 \%$ to practices with $3-7$ doctors and $10.2 \%$ to practices who have $10-15$ doctors.

This study includes data counted in 3-year time steps, a period considered relevant for the manifestation of trends and changes. It has, as a starting point, a dataset that was attained in 2015 because of the analysis of the 10 best GOOGLE-SEO indexing websites of dental offices in Oradea over a period of half a year (December 2014-May 2015) [65]. This exploratory study mainly looked at the aspect of internationalization and the potential of attracting foreign tourists through various content elements, such as multilingual communication and information about medical tourism.

The second study (2018) expanded the area of the systematic analysis to the entire professional body and all dental practice websites within the same geographical perimeter; it delved into the specifics of the content published on the websites, with a focus on entrepreneurial aspects. A quantitative and qualitative analysis of all functional websites was carried out and a series of 42 categories of information was inventoried. Through the research, we integrated a new component, that of Facebook communication (active personal and professional Facebook accounts) as the detailed analysis of the websites revealed an above average interest (65\%) in this form of social media compared to other options [66,67].

The third study (2021) continued the quantitative and qualitative analysis of the same professional body, following the two already traditional communication branches: websites (with 42 items investigated) and Facebook (personal as well as professional accounts) recording the occurring changes.

The working hypothesis was that the more categories of information a website contains, the more it shows the management's interest in implementing a comprehensive communication strategy. This approach is a basic element in achieving solid economic and social sustainability and becomes part of the doctor's entrepreneurial initiative.

In order to achieve the aim of the research, it was necessary to find concrete elements that would allow the analysis of information categories displayed on a website. We grouped the identified elements into six major categories of information; these are useful in assessing the complexity of a website, as well as in measuring its evolution at distinct moments.

The six major categories from our framework contain the following elements: 
- identification details of professional practice: $\log$, information on access to the practice by Google Map, smartphone, online communication via email;

- professional degrees of practitioners: diploma and certificates of the doctors;

- $\quad$ scientific information: articles, blog, newsletters;

- information related to the legal obligations: reference to a regulatory framework, link to official institutions, Cookie's policies;

- medico-economic information;

- related to financial aspects: card payment facilities, links exchange, special offers, tariffs, associated affaires (shop, paid courses, radiology); specialized offer for kids/teenagers; services with high added value: aesthetic, surgery or implantology, events; reference to medical tourism: amenities regarding travel accommodation, or airport transfer, reference to specialized tourism providers;

- information concerning communication tools used: social media on the site-Instagram, Facebook, LinkedIn, Twitter; other applications as Flickr, Pinterest, Skype, Vimeo, YouTube; Multilingual Communication-English, French, German, Hungarian or Italian versions of the site, testimonials, treated cases, online registration facility, photo gallery, videos.

This framework overlaps almost entirely with that recommended by the most recent Communication Charter of French Dentists (2019) [55].

In March 2020, the Romanian authorities declared a State of Emergency, which stated "an exceptional condition which could not be foreseen [ ... ] an extraordinary situation which required extraordinary measures" [68]. Initially proclaimed for 30 days, they subsequently extended it until 15 May [69] and temporarily suspended the activity of most dental offices. However, despite the general panic and confusion, dentists who wanted to open their offices to the public and complied with the legal regulations in force regarding the prevention and limitation of the spread of COVID-19 infection could receive special approval and perform emergency dental interventions [70]. The Romanian College of Dentists has established a special Register for every county that contained the identifier of all private doctors who received approval to continue their activity during the pandemic [71]. The quantitative and qualitative analysis of these offices from the point of view of their websites and Facebook profiles followed the same paradigm as in 2018, with an increased focus on pandemic-related information content.

\section{Results}

\subsection{Websites and Facebook Profiles (Personal and/or Professional)}

The evolution of the number of websites is as follows, according to Figure 1: 21 websites in 2015, 26 in 2018, and 39 in 2021. Following an analysis carried out from a comparative perspective for the period 2015-2018, it was found that, in relation to the number of authorizations, $4.9 \%$ of dentists had, as owner or coordinator, an active website in 2015, while $5.9 \%$ of authorized dentists had an active website in 2018 [66]. In 2021, the percentage of doctors who were owners or coordinators of websites increased to $9.1 \%$ of the total.

In terms of the total number of functional websites in 2015, 4 websites disappeared in 2018, when 9 new websites appeared. In 2021, 6 sites identified in 2015 and 2 functional sites in 2018 disappeared and a significant number of 21 new sites were added. Out of the total of 51 sites that existed between 2015-2021, we find the existence of a long-standing core of 11 sites, which remained active throughout the investigated period. They are an element of business sustainability and show an understanding of the communication component of the profession. 




Figure 1. Evolution of Oradea dentists' websites (2015-2021). Legend: in blue-sites that appeared in 2015; in yellow-sites that appeared in 2018; in gray-sites that appeared in 2021; in the compact color area-websites that have remained active; in the gradient area-websites whose status has changed over time; in shaded area-the websites that disappeared.

The comparative analysis of the elements presents on the websites of the practices in 2018 and 2021 (Table 1) highlights some spectacular increases, which we can put mainly in relation to the growing concern for business sustainability.

Table 1. Categories of information for the websites of authorized dentists in Oradea (2018-2021).

\begin{tabular}{|c|c|c|c|c|c|c|}
\hline \multirow{2}{*}{$\begin{array}{c}\text { Year } \\
\begin{array}{c}\text { Categories of } \\
\text { Information }\end{array}\end{array}$} & \multicolumn{2}{|c|}{$\begin{array}{c}2018 \\
\text { (26 Websites Found) }\end{array}$} & \multicolumn{2}{|c|}{$\begin{array}{c}2021 \\
\text { (39 Websites Found) }\end{array}$} & \multicolumn{2}{|c|}{$\begin{array}{l}\text { Evolution } \\
2018 \text { to } 2021\end{array}$} \\
\hline & nr. Websites & Percentage & nr. Websites & Percentage & nr. Websites & Percentage \\
\hline Aesthetic & 14 & $54 \%$ & 16 & $41 \%$ & 2 & $14 \%$ \\
\hline Articles Blog & 6 & $23 \%$ & 10 & $26 \%$ & 4 & $67 \%$ \\
\hline $\begin{array}{l}\text { Associated affaires } \\
\text { (shop, paid courses, } \\
\text { radiology) }\end{array}$ & 8 & $31 \%$ & 12 & $31 \%$ & 4 & $50 \%$ \\
\hline Card payment facilities & 5 & $19 \%$ & 7 & $18 \%$ & 2 & $40 \%$ \\
\hline Cookie policies & 4 & $15 \%$ & 20 & $51 \%$ & 16 & $400 \%$ \\
\hline $\begin{array}{l}\text { Diploma, Certificates of } \\
\text { doctors for Articles, } \\
\text { Conference Programs }\end{array}$ & 6 & $23 \%$ & 5 & $13 \%$ & -1 & $-17 \%$ \\
\hline Events & 2 & $8 \%$ & 5 & $13 \%$ & 3 & $150 \%$ \\
\hline Flickr & 2 & $8 \%$ & 0 & 0 & -2 & $-100 \%$ \\
\hline For kids/For teenagers & 3 & $12 \%$ & 10 & $26 \%$ & 7 & $233 \%$ \\
\hline Google + & 10 & $38 \%$ & 1 & $3 \%$ & -9 & $-90 \%$ \\
\hline Google Map & 23 & $88 \%$ & 36 & $92 \%$ & 13 & $57 \%$ \\
\hline Implantology & 11 & $42 \%$ & 19 & $49 \%$ & 8 & $73 \%$ \\
\hline $\begin{array}{l}\text { Link to official } \\
\text { institutions }\end{array}$ & 3 & $12 \%$ & 7 & $18 \%$ & 4 & $133 \%$ \\
\hline Links exchange & 1 & $4 \%$ & 1 & $3 \%$ & 0 & 0 \\
\hline $\begin{array}{c}\text { Logo } \\
\text { Multilingual }\end{array}$ & 15 & $58 \%$ & 30 & $77 \%$ & 15 & $100 \%$ \\
\hline $\begin{array}{l}\text { Communication- } \\
\text { English version of the } \\
\text { site }\end{array}$ & 6 & $23 \%$ & 10 & $26 \%$ & 4 & $67 \%$ \\
\hline $\begin{array}{l}\text { Multilingual } \\
\text { Communication- } \\
\text { French version of the } \\
\text { site } \\
\text { Multilingual }\end{array}$ & 1 & $4 \%$ & 1 & $3 \%$ & 0 & 0 \\
\hline $\begin{array}{l}\text { Communication- } \\
\text { German version of the } \\
\text { site }\end{array}$ & 2 & $8 \%$ & 1 & $3 \%$ & -1 & $-50 \%$ \\
\hline $\begin{array}{c}\text { Multilingual } \\
\text { Communication- } \\
\text { Hungarian version of } \\
\text { the site }\end{array}$ & 4 & $15 \%$ & 3 & $8 \%$ & -1 & $-25 \%$ \\
\hline
\end{tabular}


Table 1. Cont.

\begin{tabular}{|c|c|c|c|c|c|c|}
\hline \multirow{2}{*}{$\begin{array}{c}\text { Year } \\
\text { Categories of } \\
\text { Information }\end{array}$} & \multicolumn{2}{|c|}{$\begin{array}{c}2018 \\
\text { (26 Websites Found) }\end{array}$} & \multicolumn{2}{|c|}{$\begin{array}{c}2021 \\
\text { (39 Websites Found) }\end{array}$} & \multicolumn{2}{|c|}{$\begin{array}{l}\text { Evolution } \\
2018 \text { to } 2021\end{array}$} \\
\hline & nr. Websites & Percentage & nr. Websites & Percentage & nr. Websites & Percentage \\
\hline $\begin{array}{c}\text { Multilingual } \\
\text { Communication- } \\
\text { Italian version of the } \\
\text { site }\end{array}$ & 3 & $12 \%$ & 3 & $8 \%$ & 0 & 0 \\
\hline Newsletter & 1 & $4 \%$ & 4 & $10 \%$ & 3 & $300 \%$ \\
\hline $\begin{array}{l}\text { Online communication } \\
\text { via email }\end{array}$ & 22 & $85 \%$ & 34 & $87 \%$ & 12 & $55 \%$ \\
\hline Online registration & 5 & $19 \%$ & 21 & $54 \%$ & 16 & $320 \%$ \\
\hline Photo gallery & 20 & $77 \%$ & 34 & $87 \%$ & 14 & $70 \%$ \\
\hline Pinterest & 3 & $12 \%$ & 1 & $3 \%$ & -2 & $-67 \%$ \\
\hline $\begin{array}{l}\text { Reference to a } \\
\text { regulatory framework }\end{array}$ & 1 & $4 \%$ & 9 & $23 \%$ & 8 & $800 \%$ \\
\hline $\begin{array}{l}\text { Reference to Amenities } \\
\text { regarding Travel } \\
\text { Accommodation, } \\
\text { Airport Transfer, etc. }\end{array}$ & 3 & $12 \%$ & 3 & $8 \%$ & 0 & 0 \\
\hline $\begin{array}{l}\text { Reference to specialized } \\
\text { tourism providers }\end{array}$ & 1 & $4 \%$ & 1 & $3 \%$ & 0 & 0 \\
\hline Skype & 1 & $4 \%$ & 1 & $3 \%$ & 0 & 0 \\
\hline Smartphone & 20 & $77 \%$ & 37 & $95 \%$ & 17 & $85 \%$ \\
\hline $\begin{array}{l}\text { Social Media on the } \\
\text { site-Instagram }\end{array}$ & 3 & $12 \%$ & 15 & $38 \%$ & 12 & $400 \%$ \\
\hline $\begin{array}{l}\text { Social Media on the } \\
\text { site-Facebook }\end{array}$ & 17 & $65 \%$ & 28 & $72 \%$ & 11 & $65 \%$ \\
\hline $\begin{array}{l}\text { Social Media on the } \\
\text { site-LinkedIn }\end{array}$ & 4 & $15 \%$ & 14 & $36 \%$ & 10 & $250 \%$ \\
\hline $\begin{array}{l}\text { Social Media on the } \\
\text { site-Twitter }\end{array}$ & 6 & $23 \%$ & 14 & $36 \%$ & 8 & $133 \%$ \\
\hline Special offers & 2 & $8 \%$ & 6 & $15 \%$ & 4 & $200 \%$ \\
\hline Surgery & 12 & $46 \%$ & 18 & $46 \%$ & 6 & $50 \%$ \\
\hline Tariffs & 14 & $54 \%$ & 23 & $59 \%$ & 9 & $64 \%$ \\
\hline Testimonials & 4 & $15 \%$ & 12 & $31 \%$ & 8 & $200 \%$ \\
\hline Treated Cases & 10 & $38 \%$ & 13 & $33 \%$ & 3 & $30 \%$ \\
\hline Videos & 3 & $12 \%$ & 8 & $21 \%$ & 5 & $167 \%$ \\
\hline Vimeo & 2 & $8 \%$ & 1 & $3 \%$ & -1 & $-50 \%$ \\
\hline YouTube & 1 & $4 \%$ & 4 & $10 \%$ & 3 & 0 \\
\hline
\end{tabular}

There is a significant increase of sites, from one in 2018 to nine in 2021, which contains references to a regulatory framework (because sites must comply with professional regulations). Despite the growing interest, the nine sites represent only $23 \%$ from total. Information delivered to the consumers (patients) regarding existing regulatory and control institutions is published by less than a fifth of the total sites (although in absolute terms, the number of publishing sites has doubled compared to 2018).

Alignment with European regulations regarding the General Data Protection Regulation [72] saw a significant increase from 4 sites (15\% of the total in 2018) to 20 sites (51\% of the 2021 total). However, about half of the functional websites in 2021 still need to make changes for compliance.

Other notable increases appear regarding various forms of social media: Instagramfrom $12 \%$ in 2018 to $38 \%$ in 2021 (in absolute terms, this increase from 3 to 15 sites is spectacular), LinkedIn-from 15\% in 2018 to $36 \%$ in 2021 (3.5 times increase in absolute terms), Twitter-from $23 \%$ in 2018 to $36 \%$ in 2021 (2.3-fold increase in absolute terms), Facebook-from 65\% in 2018 to $72 \%$ in 2021 (from 17 sites in 2018 to 28 in 2021).

Even if there were some references to some internet applications in 2018, such as Flickr $(8 \%)$, Vimeo $(8 \%)$ or Pinterest $(12 \%)$, they almost completely disappeared from the websites of the 2021 year. Moreover, only one dentist provided a reference to Skype services on his website in 2018 and no changes have occurred since then. 
The possibility of communication via e-mail is offered at an overwhelming percentage of sites (from 85\% in 2018 to $87 \%$ in 2021). In 2021, we can observe a spectacular (4-fold compared to 2018) increase in the number of sites which offers online registration services. The evolution from 5 sites in 2018 which offered this option to 21 in 2021, means that today more than half (54\%) of the functional sites include the option in comparison with $19 \%$ in 2018.

Patients could use the Google Map services on 92\% of the websites of 2021 . This service is growing in popularity, being present on only $88 \%$ of the websites of 2018 . In absolute terms, this means a significant increase of 13 sites in comparison with the 2018 data.

The number of sites which contain client testimonials has increased by three times (in absolute numbers), which proves that the businesses understood that third party opinions can boost their public image, which is a significant component of their business sustainability. A third (31\%) of the websites in 2021 present this information in their content, compared to only $15 \%$ in 2018.

The presence of information about the fees charged for each type of intervention has increased from 54\% in 2018 to 59\% in 2021 (from 14 to 23 sites in absolute terms). On top of this, it must be noted, the only moderate interest in diversifying the payment options available to the clients (card payment facilities are present on 7 sites in 2021, a slight increase compared to 2018).

In order to improve their sustainability by finding additional sources of income, more and more doctors have identified new target groups, such as teenagers and kids. The number of practices displaying specific services for these age groups has increased from 3 to 10 , a 3 -fold increase, so that $26 \%$ of practices with websites offer these options in 2021 , compared to only $12 \%$ of the total in 2018 . Addressing these target groups means also the diversification of offered services (e.g., aesthetics for teenagers or adults).

More and more websites have appeared with information about new procedures such as implantology (11 websites in 2018 compared to 19 in 2021) or surgery (12 websites in 2018 compared to 18 in 2021).

In order to be permanently in touch with its client base, some professionals have chosen to regularly publish blog articles (an increase from 6 sites in 2018 to 10 in 2021, which means a quarter of practices' sites). Other methods adopted in this category are special offers (the number of sites using these tripled compared to 2018, but do not exceed $15 \%$ of the total of 39 sites), and newsletters (we can see an increase from 1 site in 2018 to 4 in 2021).

The number of sites with a logo and a motto has doubled, so that in 2021, 30 out of 39 practices are using a logo on their website, compared to 15 sites out of 26 in 2018 . Percentagewise, this represents an increase from a share of 55\% in 2018 to $77 \%$ in 2021 . Because images could be more appealing than text, almost $90 \%$ of all websites had a photo gallery in 2021 . Compared to 2018, we can see (in absolute terms) a 70\% increase in the number of websites that are making use of a photo gallery (the majority uses for this purpose the patients' photos to illustrate their positive evolution before and after treatment).

It is surprising that even though Oradea is bordering Hungary, and has many citizens with Hungarian language as their parent language, in 2021 only $8 \%$ of the sites (meaning 3 offices) have a Hungarian version, a decreasing number compared to the 4 websites existing in 2018. The German and French version websites also decreased from 2 sites to 1 ; unchanged, from one period to another, is the number of the websites with Italian translations ( 3 sites). the situation of English version websites is surprising: compared to 2018 (when 6 out of 29 offices had English translated sites), in 2021 there was an increase of these sites by 4 , meaning an increase in absolute terms with $67 \%$.

There was no change in the number of websites containing information about travel accommodation, airport transfer (3 sites in 2018 and 2021), or those that reference to links of specialized tourism providers who organize trips (1 site in 2018 and 2021). 
The results of the analysis show that from one examined period to another, the situation underwent some major and even surprising changes. In 2018, 49.2\% of all analyzed dentists did not have a Facebook profile, while in 2021, this value increased to $56.49 \%$ (Table 2).

Table 2. Presence/absence of Facebook profiles (2018-2021).

\begin{tabular}{ccccc}
\hline Year & \multicolumn{2}{c}{2018} & \multicolumn{2}{c}{$\mathbf{2 0 2 1}$} \\
\hline Dentists & Number & Percentage & Number & Percentage \\
\hline With Facebook profile & 228 & $50.8 \%$ & 188 & $43.51 \%$ \\
Without Facebook profile & 221 & $49.2 \%$ & 244 & $56.49 \%$ \\
Total & 449 & $100 \%$ & 432 & $100 \%$ \\
\hline
\end{tabular}

The authors of this study also counted the dentists' Facebook profiles type, namely personal or professional. The conclusion was mixed, as we found that some of them have only a personal profile, only a professional profile or both of them (Table 3).

Table 3. Detailed presentation of Facebook profiles (2018-2021).

\begin{tabular}{|c|c|c|c|c|c|}
\hline \multirow{2}{*}{\multicolumn{2}{|c|}{$\begin{array}{c}\text { Year } \\
\text { Doctors }\end{array}$}} & \multicolumn{2}{|c|}{2018} & \multicolumn{2}{|c|}{2021} \\
\hline & & Number & Percentage & Number & Percentage \\
\hline \multirow{3}{*}{ With Facebook profile } & $\begin{array}{c}\text { personal profile }+ \\
\text { professional profile }\end{array}$ & 48 & $10.70 \%$ & 33 & $7.64 \%$ \\
\hline & $\begin{array}{l}\text { only personal } \\
\text { profile }\end{array}$ & 163 & $36.30 \%$ & 124 & $28.70 \%$ \\
\hline & $\begin{array}{l}\text { only professional } \\
\text { profile }\end{array}$ & 17 & $3.78 \%$ & 31 & $7.18 \%$ \\
\hline \multicolumn{2}{|c|}{ Without Facebook profile } & 221 & $49.22 \%$ & 244 & $56.49 \%$ \\
\hline \multicolumn{2}{|c|}{ Total } & 449 & $100 \%$ & 432 & $100 \%$ \\
\hline
\end{tabular}

According to our findings, we can see a decrease of 3\% in the number of doctors using two different FB account types simultaneously (personal and professional)-(from 10.7\% in 2018 to $7.6 \%$ in 2021) and a decrease (also) of the doctors who are using only personal type of Facebook profiles (from $36.3 \%$ in 2018 to $28.7 \%$ in 2021). Comparing with the aforementioned trends, we can see a notable upward trend in the appetite for using only professional type Facebook accounts (from 3.78\% in 2018 to $7.18 \%$ in 2021). Although the numbers are small as a percentage, the increase shows a trend of shifting interest towards exclusive professional-type communication and the understanding of the importance of communicating more cleanly and efficiently.

\subsection{Communication during Pandemic}

At the start of pandemic in the beginning of 2020, the government imposed extraordinary measures which drastically reduced the number of dental offices that can provide medical services. The crisis of the moment is easily visible as only 18 dental practices in Bihor County were authorized to operate during the first COVID-19 lock-down period (March-April 2020). This is a very low number, considering that there were 1101 doctors registered in Bihor County (in 2020), of which 742 were active (according to the report on the national website of the National College in December 2020).

From the allowed practices, 16 were in the city of Oradea and 2 in other parts of the county. Of the doctors practicing in the city of Oradea, only 4 had a functioning website (of which only 1 was used proactively) and 13 had Facebook profiles (6 of them a personal account, 4 of them a professional account, 3 of them had both).

Of the 4 websites, only 1 stood out for its professionalism in communicating various information regarding COVID-19. The owner of the website (https:/ / cliniciledrleahu.ro) 
was a new dental office, part of a national chain, that entered the dental market in 2019 (shortly before the pandemic) and is managed by a dentist-entrepreneur. It came with the advantage of a centralized communication campaign, undoubtedly made by a marketing specialist and used as communication tools with suggestive photos with great public impact (masks, protective suites, etc.), details of their dentist's appearances in the written and visual media, participation in various webinars, description of protocols, operating authorization, updated prices and statistics and suggestive texts and videos. Furthermore, they used carefully chosen suggestive texts in order to convey the most reassuring information in an accessible form. This office is very business oriented and the use of their professional Facebook profile is exemplary, following the model used on their website.

\section{Discussions}

The first striking find of our research is the surprising trend in the decreasing number of practicing doctors. This is very unusual, as Oradea is an expanding market, determined by the industrial and demographic development of the city, which is flooded every year by fresh graduates trained especially by the local university. The reason for the aforementioned situation could be that, beyond the suspension of activity for personal reasons (such as migration of the workforce abroad or maternity leave), practicing dentistry has not only a vocational but also a strong entrepreneurial component; however, most newcomers do not have the financial and logistical resources to ensure the sustainability of a new business. Another phenomenon that started years ago and continues today is the workforce migration to other countries. In order to better understand the behavior reactions of dentists, we mention that in Romania the dental medical services are covered only to a tiny extent by state-sponsored social insurance. Furthermore, there are no public health programs in the dental field. We can therefore conclude that the average patient is visiting his dentist of choice and is paying for the full cost of his treatment himself.

\subsection{Websites and Facebook Profiles}

Through their content, websites show a clear trend of increasing interest and concern for maintaining communication with customers in order to grow the number of customers and strengthen their loyalty. The rising quality of the content of the websites, various profiles or both can be interpreted in the sense of doctors' concern to find viable solutions for improving their sustainability and survival in a competitive market. The diversification of their offerings preoccupies more and more specialists, a situation which implies both an increase in complexity of their businesses (possibly through the acquisition of knowhow and sophisticated equipment) and a rise in the added value of the services. For example, they particularize more and more offerings for different age groups with specific needs (e.g., kids or teenagers) or introduce new procedures such as implantology or surgery.

The content seems to become more and more focused on actual practice: there is not much interest in presenting various references to diplomas, certificates, published articles or conference attendance, although they could be persuasive. The preferred way to convey to patients a description of offered services is not text, but images. Websites overwhelmingly show photo galleries, especially comprising mouths and minor parts of faces, faces anonymized with covered eyes and patients in dental armchairs. Sites have an obvious orientation toward the sensibility of the common patient, with beautiful photos, without technical details or shocking images (blood, cavities, wounds). The cases exhibited using images and videos are of their patients made and distributed with their consent, which gives even more credibility to the practice. In order to further differentiate themselves in a competitive market, medical entrepreneurs are increasingly understanding the importance of defining their identities by visual markers (e.g., logos and mottos).

The interest in helping customers to choose the best services resulted in publishing information on tariffs (on almost all sites) because they could become a powerful argument for accessing the services of a certain practice. Some are even offering card payment facilities and occasional promotions. The prospect of tourism development in Oradea 
made medical tourism appear (at the initial time of the research) as a promising option for widening the pool of potential customers and ensuring the sustainability of the businesses. However, a decreasing trend is manifesting itself, as the years go by, in terms of the references to medical tourism on websites. Although doctors are still interested in having foreign patients, they are using other communication channels for achieving this goal.

The elements regarding the legal-medical category are mandatory and are increasingly present, but there is ample space for improvement. These elements are imposed mainly by European legislation and consists of, for example, cookie policies, references to a regulatory framework, links to official institutions, etc.

An important field of interest are the aspects related to communication and contact with actual or potential patients. We can see notable increases regarding the use of various forms of social media. For example, Instagram has become an element worth exploring from the perspective of entrepreneurship in the dental practice. At the same time, Facebook's growth is more modest but continues to be the most significant presence (on more than half of the sites) and as such remains the best represented in doctors' choices. The disappearance of references to various internet applications (such as Vimeo, Flickr) is suggesting that their services are irrelevant for this type of business, being replaced by other resources. For example, the lack of Skype referrals on websites could relate to the emergence of new accessible communication tools that have grown in popularity, such as Facebook's Messenger. Another unresearched tool which is gaining momentum is the WhatsApp application, used mainly via mobile phones [73].

The interest in communication via email remains a constant priority despite the significant evolution of other communication platforms. Another element used to increase the patients' access to service planning is the possibility of online registration, which becomes an element of attractiveness regarding the offered services. The number of sites which contain client testimonials has increased by three times (in absolute terms). The presence of comments on social networks generated by various users provides useful feedback to other potential clients through experience sharing [74]. As a consequence of widespread use of smartphones in 2021, 92\% of websites make use of Google Maps in order to help to locate the businesses' addresses (of course, these are also in clear-text).

We consider the lack of multilingual presentation of the sites interesting, given the cosmopolitan nature of the city. For example, in 2021, barely a quarter of the practices surveyed considered it useful to offer patients an English version of their website. There is also a significant lack of representation of practices in Hungarian, Italian, French or German languages. We can relate this to a decrease in interest for attracting foreigners in dental tourism through integrated tourist packages. However, the linguistic component maintains a major role in communication; for example, there is a recommendation made to French dentists [55] to inform patients through digital media by the languages used in their day-to-day practice.

Blog articles or newsletters are elements which, through the dynamics of their content, should keep patients interested and informed. However, few doctors are using them because they are time- and energy-consuming and their consumption depends on the quality of their content. The disappearance of some features is not just the result of individual choices, but the effect of changes in technology; this is the case of the 2019 withdrawal of the social networking app G+ by Google.

The question that remains, in this context, is if the dentists do not use the communication potential of their website, a trend also described in the literature [37,50], then what is their preferred communication form in public space? Given the notoriety of Facebook as a privileged and accessible form of social media, we have also investigated the professional identity of these doctors on Facebook.

Given that there is a decrease of registered licensed physicians in 2021 compared to 2018, we have found that the number of Facebook account holders has also decreased. This may have several explanations: on the one hand, there are doctors who do not really pay attention to communication using social media, being content with a certain number of 
loyal patients and being satisfied with the number of new patients who come through wordof-mouth recommendation; on the other hand, it can also be a generational phenomenon, with doctors from younger generations migrating to other forms of social media such as Instagram and Twitter. It could be necessary to proceed to a detailed investigation into these other forms of social media.

The personal Facebook accounts involve the use of a mix of personal and family information (text and images), various shares, positive or negative reactions to a large variety of events, messages marked emotional or neutral, with dental-related text or images slipped in between. The proportion of doctors with personal profiles decreased by almost $8 \%$ in 2021 compared to 2018, which is a significant percentage. We can see the same descending trend for dual account holders, personal and business, but at a lower pace. The only increase we recorded is for the professional accounts, which share have almost doubled.

Our study did not envisage to review the content of the various Facebook profiles, but to identify the doctors who are using Facebook as a vehicle for communication. Facebook, which is in 2021 the biggest social networking service based on global reach and total active users [75], is a communication tool for half of the professionals in the studied field and more and more are exploiting the platform's business potential.

In the today's market, a successful business can no longer separate its online presence from its physical presence. Briciu and Briciu (2021) note that simply existing in the online environment can maintain the relationship with the public and strengthen brand awareness [76].

\subsection{Pandemic Context}

Regardless of the global imperative for universal health coverage by delivering quality health services [77], the COVID-19 pandemic generated the suspension of office activity with dual consequences: the lack of income for doctors which challenged the principles of sustainability; and the impossibility for patients to have free access to oral health services.

Forced to suspend their activity, doctors ended up being unable to help their patients to manage a state of chaos and significant uncertainty. This situation in Romania does not seem to be unique, since Ahmed et al. (2020) [46] registered the presence of anxiety and fear in 30 different countries worldwide. Confusion, irritation and a lack of legislative and administrative coherence marked March-May 2020.

Deciding to open the office during the emergency period also meant taking supplementary organizational responsibilities: ensuring the endowment of offices (special protective equipment and disinfectants-problematic in a global shortage); organizing the triage of patients; renewing disinfection protocols; avoiding procedures that can produce unnecessary aerosols; and assuring proper ventilation. Beyond the fear of contamination, all this led to a sudden increase in costs, and doctors do not know how to assume these costs strategically.

Some specific challenges marked the communication during this period: miscommunication between authorities, lack of communication between authorities and private dental offices, disorientation and hesitation of the dental professionals. The lack of scientific information regarding the best ways to secure dental offices procedures has led to a general lockdown, inadequate dental care, and general frustration.

Observing the websites and Facebook accounts of licensed dentists or licensed practices or clinics during the emergency, we found that most information was communicated using Facebook. Some professionals tried to increase their own visibility through daily posts in order to enhance the confidence of their own patients and to win new patients.

Regarding the messages transmitted, there was some confusion because some dentists mixed their personal opinions with the official point of view. In this period, the citizens have four sources of information: first, from international bodies; second, from decision-makers at the national level; third, from dentists; and fourth, from the media. Reality has shown that citizens have taken public media and parts of it that covered science, medicine and public health without subject-matter expertise as their mainstream information source [78]. 
The state of uncertainty and general panic, associated with the hesitant and sometimes delayed reactions of international authorities, represented a fertile ground for a mixture of true and fake news.

This study may open up new avenues for reflection, in the perspective of potentially new crisis events, similar to the one of the spring of 2020. In the COVID-19 pandemic, the World Dental Federation recommended using tele-dentistry for patient consultations among the measures to be implemented globally to ensure the safety of patients and the medical team in case of dental interventions to prevent and control the spread of COVID19 [79]. Doctors have a great responsibility to communicate, so that healthcare is safe for both patients and healthcare professionals at the same time.

\section{Conclusions}

The paper aimed to identify the strategies used in online communication by dentists in the city of Oradea, Romania, before, during and after the COVID-19 period. In the period of 2015-2021, in a complex digital landscape, it turned out that the communication and persuasion potential of websites and Facebook profiles remains under-exploited. There is space for a more effective use of social media, and we can link this to the infancy of entrepreneurship.

Dentists lack skills in medical entrepreneurship and often intuitively do what is necessary to optimize their relationship with patients. However, communication must become an integrated approach to ensure sustainability in a competitive and sensitive environment. Although the number of websites increased significantly between 2015 and 2021, the number of owners or coordinators did not exceed $10 \%$ of the total number of registered doctors, which shows enormous potential for growth. In the inventoried websites, we found references to 135 doctors, which represent only one third of the entire professional branch (data for 2021). There are several explanations regarding the positive dynamics of websites, among which we note the growing interest in using an increasing range of tools that can ensure the sustainability of a business and the emergence of a generation (because of the generational shift) for whom the internet and its extensions are natural tools. A website is a long-term investment, a sustainable communication channel containing a core of common information that does not need frequent refreshments.

The dynamics of Facebook accounts reveal that even if there is a more accessible and simpler tool to operate with (compared to a webpage), it is not being exploited to its full potential. The category of Facebook account holders does not exceed an average of $50 \%$ of registered doctors at any point in the 7-year survey. On average, a third of dentists have personal Facebook accounts. There is, however, a growing interest in shifting the focus from personal accounts to professional accounts dedicated to communicating only on dentalrelated topics. An integrated approach of several forms of digital communication as part of a company's communication strategy appears in a very limited number of practices; here, either the doctor has IT and marketing knowledge and manages the applications himself, or he calls upon various specialized companies to fulfill the tasks. The disadvantage in the latter case is the significant costs involved both in short and long term, but are compensated by multiple advantages such as better advertising, better sustainability and a larger client base.

In times of crisis, such as the generalized blockage caused by the emergence of a pandemic, the communication through media channels remains the only way to maintain contact with patients and society. Most studies also unanimously recognize the effectiveness of social networks in sharing information during natural disasters and critical events [40]. The drastic reduction in the number of authorized doctors to practice the profession and the fluctuations of official information during the state of emergency, a situation marked by fear, blockages and inadequacies, has altered not only the communication between doctors and patients but also the access of the population to medical services, and as a result affected the sustainability of dentistry business assumed by the FDI in 2017. There are several limitations of this study given by the lack of freely available financial data that can prove 
an immediate consequential relationship between developed communication strategies and increased business sustainability. However, this relationship is proven indirectly by the growing role of digital entrepreneurship in the most successful businesses. Furthermore, the doctors are reluctant to disclose financial aspects of their business or elements that could distinguish them in a competitive market.

The data is reliable because it provides an image of an entire professional branch at two distinct moments in the city of Oradea. Because of the dynamics of the field, a certain volatility of the data is possible, but we consider that at proximal timeframe the data variations are minimal. Based on the results, we can extrapolate and advance hypotheses regarding the behavior of dentists in any similar socio-economic environment. The community, which is more and more informed and receptive to sustainable practices respectful with the environment and the citizen, will look for aspects of these goals on the communication platforms of the dentists considering them as a selection criteria in choosing the provider of dental services. We appreciate that doctors who do not adapt to the new communication demands will encounter increased difficulty in expanding their client base.

Digital applications are very important for entrepreneurs in their effort to enhance their strategies and achieve better performance. The paper opens up practical perspectives for dentists and other specialists who understand the need to approach their profession from an entrepreneurial point of view, too. Depending on their business objectives, they can implement different digital communication strategies: they can use accessible and inexpensive communication tools by themselves, or can request assistance from various companies in order to build complex communication campaigns and marketing strategies. Dental professionals can thus take a more active role in social media to expand their customer base and interact with their patients more closely [14].

Further research can be conducted to examine various medical areas in other cities in Romania or abroad, which can serve as the bases of some comparative studies. The article can also be useful for other stakeholders: for example, for policy makers who do not always have the complete view of the specifics of an activity where, in order to provide good quality services, there is a need of long-term investments in human and material resources which can be made only in a sustainable business model. It can further emphasize the need for specialized training in medical schools and professional associations, so that the students and the practitioners have not only professional know-how but also basic skills in various forms of entrepreneurship.

In this article, we have specifically discussed various methods of communication between doctors and patients. Another important aspect of communication in this field is the one between the doctors belonging to different offices. The patient's right to exercise his free choice of choosing the attending physician generates the need for an easy and secure access of the specialists to the data belonging to the history of the patient's dental treatments. One solution to achieve this goal is the blockchain, a decentralized and inexpensive technology that can revolutionize patient care management applications. This technology enables (when applied) a new level of trust, traceability and transparency [80]. By adopting such solutions, we can achieve a significant improvement in the economic and social sustainability of the dental activity; this aspect qualifies it to become an interesting topic in the following researches.

Last but not least, this article can help in defining the portrait of an entrepreneurial dentist. Just as we talk about doctorpreneurs (professionals interested in healthcare innovation and entrepreneurship) [81], we could also talk in perspective about dentistpreneurs, meaning dentists committed to business sustainability who are open to permanent innovation and are using various communication tools in order to maximize their customer base. 


\begin{abstract}
Author Contributions: Conceptualization, A.K. and F.C.; methodology, A.K. and F.C.; validation A.K.; formal analysis, F.C.; investigation, F.C.; resources, F.C. and A.K.; data curation, F.C. and A.K.; writing-original draft preparation, A.K. and F.C.; writing-review and editing, F.C.; visualization, A.K.; supervision A.K. and F.C. All authors have read and agreed to the published version of the manuscript.
\end{abstract}

Funding: This research received no external funding.

Institutional Review Board Statement: Not applicable.

Data Availability Statement: Data analyzed in this study are openly available at locations cited in the reference section.

Acknowledgments: Marton Gyorgy Pantel, Romanian Dental Association of Private Practitioners; Vlad Cristian Deac, Romanian Dental Association of Private Practitioners and Bihor County's Employers Federation.

Conflicts of Interest: The authors declare no conflict of interest.

\title{
References
}

1. Te Brake, J.H.M.; Bouman, A.M.; Gorter, R.C.; Hoogstraten, J.; Eijkman, M.A.J. Using the Maslach Burnout Inventory among Dentists: Burnout Measurement and Trends. Community Dent. Oral. Epidemiol. 2008, 36, 69-75. [CrossRef]

2. Ocek, Z.A.; Vatansever, K. Perceptions of Turkish Dentists of Their Professional Identity in a Market-Orientated System. Int. J. Health Serv. 2014, 44, 593-613. [CrossRef] [PubMed]

3. Singh, A.; Purohit, B. Dental Entrepreneurship: A Transitional Phase to Generation Next. Adv. Life Sci. Technol. $2012,2,25$.

4. Harris, M. Profitable Dentistry: A Teaching Case in Entrepreneurship. Bus. Educ. Innov. J. 2011, 3, $103-106$.

5. da Silva Garcia, B.; de Campos, R. An Application of Business Process Management in a Dental Clinic. Gepros Gestão da Produção Operações e Sistemas 2020, 15, 102. [CrossRef]

6. Antoniadou, M.; Devetziadou, M. Sensory Branding: A New Era in Dentistry. Online J. Dent. Oral Health 2020, 3, 1-8. [CrossRef]

7. Henry, R.K.; Molnar, A.; Henry, J.C. A Survey of US Dental Practices' Use of Social Media. J. Contemp. Dent. Pract. 2012, 13, 137-141. [CrossRef] [PubMed]

8. Neville, P.; Waylen, A. Social Media and Dentistry: Some Reflections on e-Professionalism. Br. Dent. J. 2015, 218, 475-478. [CrossRef] [PubMed]

9. Ventola, C.L. Social Media and Health Care Professionals: Benefits, Risks, and Best Practices. Pharm. Ther. 2014, 39, 491-520.

10. Snyman, L.; Visser, J.H. The Adoption of Social Media and Social Media Marketing by Dentists in South Africa. S. Afr. Dent. J. 2014, 69, 258, 260-264.

11. Aguirre, O.; Mariño, R.; Medina-Solís, C.; Maupomé, G. Use of Internet for General and Dental Health along Acculturation Features in a Sample of Mexican Americans. Ethn. Dis. 2017, 27, 443-452. [CrossRef]

12. Emmert, M.; Halling, F.; Meier, F. Evaluations of Dentists on a German Physician Rating Website: An Analysis of the Ratings. J. Med. Internet Res. 2015, 17, e3830. [CrossRef] [PubMed]

13. Bahabri, R.H.; Zaidan, A.B. The Impact of Social Media on Dental Practice Promotion and Professionalism amongst General Dental Practitioners and Specialists in KSA. J. Taibah Univ. Med Sci. 2021, 16, 456-460. [CrossRef]

14. Parmar, N.; Dong, L.; Eisingerich, A.B. Connecting with Your Dentist on Facebook: Patients' and Dentists' Attitudes Towards Social Media Usage in Dentistry. J. Med. Internet Res. 2018, 20, e10109. [CrossRef] [PubMed]

15. Frenz, M. Introduction: Medical Tourism or Movement for Healthcare? Reflections on (Inter-)National Cross-Border Mobility. Glob. Public Health 2019, 14, 321-325. [CrossRef] [PubMed]

16. John, S. An Analysis of the Social Media Practices for Sustainable Medical Tourism Destination Marketing. Int. J. Tour. Policy 2017, 7, 222-249. [CrossRef]

17. Nambisan, S. Digital Entrepreneurship: Toward a Digital Technology Perspective of Entrepreneurship. Entrep. Theory Pract. 2017, 41, 1029-1055. [CrossRef]

18. Zhang, C.; Fan, L.; Chai, Z.; Yu, C.; Song, J. Smartphone and Medical Application Use among Dentists in China. BMC Med. Inform. Decis. Mak. 2020, 20, 213. [CrossRef]

19. Smith, K. 126 Amazing Social Media Statistics and Facts. Available online: https://www.brandwatch.com/blog/amazing-socialmedia-statistics-and-facts/ (accessed on 11 April 2021).

20. International Labour Organization. Defining and Measuring Remote Work, Telework, Work at Home and Home-Based Work. Available online: https://ilo.org/wcmsp5/groups/public/---dgreports/---stat/documents/publication/wcms_747075.pdf (accessed on 20 February 2021).

21. United Nations A/RES/70/1-Transforming Our World: The 2030 Agenda for Sustainable Development; United Nations: New York, NY, USA, 2015; p. 35.

22. FDI World Dental Federation. Sustainability in Dentistry. Int. Dent. J. 2018, 68, 10-11. [CrossRef] 
23. Thompson, T.; Ballard, T. Sustainable Medicine: Good for the Environment, Good for People. Br. J. Gen. Pract. 2011, 61, 3-4. [CrossRef]

24. Farrow, E. Embedding Sustainability into Clinical Medicine and Medical Education. HealthManagement 2017, 17, 369-371.

25. Wolf, T.G.; Campus, G. Changing Dental Profession-Modern Forms and Challenges in Dental Practice. Int. J. Environ. Res. Public Health 2021, 18, 1945. [CrossRef] [PubMed]

26. World Health Organization Regional Office for Europe. Circular Economy and Health: Opportunities and Risks; United Nations: New York, NY, USA, 2018; p. 110.

27. Antoniadou, M.; Varzakas, T.; Tzoutzas, I. Circular Economy in Conjunction with Treatment Methodologies in the Biomedical and Dental Waste Sectors. Circ. Econ. Sustain. 2021, 1, 563-592. [CrossRef]

28. van Boerdonk, P.J.M.; Krikke, H.R.; Lambrechts, W. New Business Models in Circular Economy: A Multiple Case Study into Touch Points Creating Customer Values in Health Care. J. Clean. Prod. 2021, 282, 125375. [CrossRef]

29. Pagan, R.; Horsfall, D. Medical Tourism Markets: Models of Sustainability. The Case of Spain and The Costa Del Sol (Malaga). Sustainability 2020, 12, 8818. [CrossRef]

30. Badulescu, D.; Badulescu, A. Medical Tourism: Between Entrepreneurship Opportunities and Bioethics Boundaries: Narrative Review Article. Iran. J. Public Health 2014, 43, 406-415.

31. Martin, N.; Sheppard, M.; Gorasia, G.; Arora, P.; Cooper, M.; Mulligan, S. Drivers, Opportunities and Best Practice for Sustainability in Dentistry: A Scoping Review. J. Dent. 2021, 112, 103737. [CrossRef] [PubMed]

32. Martin, N.; Sheppard, M.; Gorasia, G.; Arora, P.; Cooper, M.; Mulligan, S. Awareness and Barriers to Sustainability in Dentistry: A Scoping Review. J. Dent. 2021, 112, 103735. [CrossRef] [PubMed]

33. Duane, B.; Croasdale, K.; Ramasubbu, D.; Harford, S.; Steinbach, I.; Stancliffe, R.; Vadher, D. Environmental Sustainability: Measuring and Embedding Sustainable Practice into the Dental Practice. Br. Dent. J. 2019, 226, 891-896. [CrossRef]

34. Bakaeen, L.G.; Masri, R.; AlTarawneh, S.; Garcia, L.T.; Abeer, A.; Khamis, A.H.; Hamdan, A.M.; Bargain, Z.H. Dentists' Knowledge, Attitudes, and Professional Behavior toward the COVID-19 Pandemic A Multisite Survey of Dentists' Perspectives-Web of Science Core Collection. Available online: https://www-webofscience-com.am.e-nformation.ro/wos/woscc/full-record/WOS: 000605345700013 (accessed on 24 April 2021).

35. Willcocks, S. The Entrepreneurial Role in Primary Care Dentistry. Br. Dent. J. 2012, 212, 213-217. [CrossRef] [PubMed]

36. Stummeyer, C. Case Study: Digital Consulting for Dental Practices by Benchmarking. In Advances in Consulting Research: Recent Findings and Practical Cases; Nissen, V., Ed.; Contributions to Management Science; Springer: Cham, Switzerland, 2019; pp. 371-383. ISBN 978-3-319-95999-3.

37. de Lira, A.D.L.S.; Magalhães, B.M. Digital Marketing in Dentistry and Ethical Implications. Braz. Dent. Sci. 2018, 21, 237-246. [CrossRef]

38. Szabo, R.; Hortovanyi, L.; Tarody, D.; Ferincz, A.; Dobak, M. The Role of Knowledge in Entrepreneurial Marketing. Int. J. Entrep. Venturing 2011, 3, 149-167. [CrossRef]

39. Holden, A.C.L. Consumer-Driven and Commercialised Practice in Dentistry: An Ethical and Professional Problem? Med. Health Care Philos. 2018, 21, 583-589. [CrossRef]

40. Kapoor, K.K.; Tamilmani, K.; Rana, N.P.; Patil, P.; Dwivedi, Y.K.; Nerur, S. Advances in Social Media Research: Past, Present and Future. Inf. Syst. Front. 2018, 20, 531-558. [CrossRef]

41. Aichner, T.; Grünfelder, M.; Maurer, O.; Jegeni, D. Twenty-Five Years of Social Media: A Review of Social Media Applications and Definitions from 1994 to 2019. Cyberpsychol. Behav. Soc. Netw. 2021, 24, 215-222. [CrossRef] [PubMed]

42. Anderson, B.; Hardin, J.M. Social Media Credit Scoring. Available online: www.igi-global.com/chapter/social-media-creditscoring/184410 (accessed on 12 May 2021).

43. Al-Khalifa, K.S.; Al-Swuailem, A.S.; AlSheikh, R.; Muazen, Y.Y.; Al-Khunein, Y.A.; Halawany, H.; Al-Abidi, K.S. The Use of Social Media for Professional Purposes among Dentists in Saudi Arabia. BMC Oral Health 2021, 21, 26. [CrossRef] [PubMed]

44. Alkadhi, O.; Aleissa, N.; Almoharib, M.; Buquayyid, S. Influence of Social Media on the Patients for Choosing the Dental Clinic-A Cross-Sectional Survey. J. Clin. Diagn. Res. 2020, 14, 32-34. [CrossRef]

45. Chamorro-Petronacci, C.; Martin Carreras-Presas, C.; Sanz-Marchena, A.; A Rodríguez-Fernández, M.; María Suárez-Quintanilla, J.; Rivas-Mundiña, B.; Suárez-Quintanilla, J.; Pérez-Sayáns, M. Assessment of the Economic and Health-Care Impact of COVID-19 (SARS-CoV-2) on Public and Private Dental Surgeries in Spain: A Pilot Study. Int. J. Environ. Res. Public Health 2020, $17,5139$. [CrossRef]

46. Ahmed, M.A.; Jouhar, R.; Ahmed, N.; Adnan, S.; Aftab, M.; Zafar, M.S.; Khurshid, Z. Fear and Practice Modifications among Dentists to Combat Novel Coronavirus Disease (COVID-19) Outbreak. Int. J. Environ. Res. Public Health 2020, 17, 2821. [CrossRef]

47. Spallek, H.; Turner, S.P.; Donate-Bartfield, E.; Chambers, D.; McAndrew, M.; Zarkowski, P.; Karimbux, N. Social Media in the Dental School Environment, Part A: Benefits, Challenges, and Recommendations for Use. J. Dent. Educ. 2015, 79, 1140-1152. [CrossRef]

48. Neville, P. Social Media and Professionalism: A Retrospective Content Analysis of Fitness to Practise Cases Heard by the GDC Concerning Social Media Complaints. Br. Dent. J. 2017, 223, 353-357. [CrossRef] [PubMed]

49. Hazzam, J.; Lahrech, A. Health Care Professionals' Social Media Behavior and the Underlying Factors of Social Media Adoption and Use: Quantitative Study. J. Med. Internet Res. 2018, 20, e12035. [CrossRef] [PubMed]

50. Nichols, L.C.; Hassall, D. Quality and Content of Dental Practice Websites. Br. Dent. J. 2011, 210, E11. [CrossRef] [PubMed] 
51. Kravitz, D.A.S.; Bullock, A.; Cowpe, J.; Barnes, E. EU Manual of Dental Practice 2015; CED Council of European Dentists: Brussels, Belgium, 2015.

52. Ordre National des Chirurgiens-Dentistes de France Charte Ordinale Relative à la Publicité et à L'information Dans les Médias. 2014. Available online: https://www.boussinesq.fr/wp-content/uploads/2018/10/CHARTE_INFO_MEDIAS.pdf (accessed on 4 October 2021).

53. Ordre National des Chirurgiens-Dentistes de France Charte Ordinale Applicable Aux Sites Internet Professionnels des ChirurgiensDentistes. 2015. Available online: https:/ / docteur-pierre-etchandy-chirurgiens-dentistes.fr/charte-ordinale-applicable-auxsites-internet-professionnels-des-chirurgiens-dentistes / (accessed on 12 October 2021).

54. Conseil d'Etat Règles Applicables Aux Professionnels de Santé en Matière D'information et de Publicité. 2018. Available online: https: / / www.vie-publique.fr/rapport/37461-regles-applicables-aux-professionnels-de-sante-en-matiere-dinformation (accessed on 12 October 2021).

55. Ordre National des Chirurgiens-Dentistes de France Charte Ordinale Relative à La Communication Du Chirurgien-Dentiste -En Date Du 13 Février. 2019. Available online: https:/ /www.dynamiquedentaire.com/wp-content/uploads/2019/02/charte_ publicite-chirurgiens-dentistes.pdf (accessed on 13 April 2021).

56. General Dental Council Standards for the Dental Team. Available online: https://standards.gdc-uk.org/Assets/pdf/Standards\% 20for\%20the\%20Dental\%20Team.pdf (accessed on 14 April 2021).

57. Moniteur Belge Loi Portant des Dispositions Diverses en Matière de Santé; Direction du Moniteur Belge: Brussels, Belgium, 2018; Chapter 9; p. 66.

58. European Commission-COM(2003)702 COM(2003)702-Report From The Commission to The European Parliament, The Council and The European Economic and Social Committee First Report on the Application of Directive 2000/31/EC of the European Parliament and of the Council of 8 June 2000 on Certain Legal Aspects of Information Society Services, in Particular Electronic Commerce, in the Internal Market (Directive on Electronic Commerce); European Commission: Brussels, Belgium, 2003.

59. Colegiului Medicilor din România Codul de Deontologie Medicala 2016/Code of Medical Ethics 2016. Available online: https:/ / www.cmbihor.ro/fisiere/codul-de-deontologie-medicala.pdf (accessed on 13 April 2021).

60. Colegiul Medicilor Dentisti din România. Codul deontologic al medicului dentist 2010/Code of Ethics for Dentists 2010. Available online: https:/ / www.monitoruloficial.ro/Monitorul-Oficial--PI--408--2010.html (accessed on 13 April 2021).

61. Colegiul Medicilor Stomatologi din România Codul Deontologic al Medicului Stomatolog 2021/Code of Ethics for Dentists 2021. Available online: http:/ /legislatie.just.ro/Public/DetaliiDocumentAfis/245940 (accessed on 25 September 2021).

62. INS-DJS Bihor/Institutul National de Statistica-Directia Judeteana de Statistica Bihor Populatia Judetului Bihor La 1 Ianuarie 2020. Available online: https://bihor.insse.ro/wp-content/uploads/2020/05/Populatia-BH-la-1-ianuarie-2020.pdf (accessed on 25 September 2021).

63. Krippendorff, K. Content Analysis: An Introduction to Its Methodology; SAGE: New York, NY, USA, 2004; ISBN 978-0-7619-1545-4.

64. Colegiul Medicilor Stomatologi din Bihor. Lista Cabinetelor Stomatologice din Bihor. Available online: http://www.cmdbh.ro/ component/content/article/17-petru-pacienti/28-lista-cabinetelor-stomatologice-din-bihor (accessed on 14 May 2021).

65. Constantin, F.; Kavoura, A. Multilingual Online Communications in Corporate Websites: Cases of Romanian Dental Practices and Their Application to Health Tourism. In Tourism and Culture in the Age of Innovation; Springer Proceedings in Business and Economics; Springer: Cham, Switzerland, 2016; pp. 185-196. ISBN 978-3-319-27527-7.

66. Constantin, F.; Kavoura, A. Websites and Facebook Profile Communication of Dentists in Oradea, Romania. In Strategic Innovative Marketing and Tourism; Springer Proceedings in Business and Economics; Springer: Cham, Switzerland, 2019; pp. 487-495. ISBN 978-3-030-12452-6.

67. Constantin, F.; Kavoura, A. Entrepreneur Without Intention with Websites as a Communication Tool: Current Trends in Romania. In Strategic Innovative Marketing and Tourism; Springer Proceedings in Business and Economics; Springer: Cham, Switzerland, 2019; pp. 1093-1101. ISBN 978-3-030-12452-6.

68. Presedintele Romaniei-Decret nr.195/16.03.2020 Decree Nr. 195/16.03.2020/Decret Privind Instituirea Starii de Urgenta Pe Teritoriul Romaniei. Available online: http:/ / mfe.gov.ro/wp-content/uploads/2020/03/0ec4303cabfafc44c332b46368643ab6.pdf (accessed on 13 April 2021).

69. Presedintele Romaniei-Decret nr. 240/14.04.2020 Decree Nr. 240/14.04.2020/Decret Privind Prelungirea Stării de Urgență Pe Teritoriul României. Available online: http:/ /legislatie.just.ro/Public/DetaliiDocumentAfis/224849 (accessed on 14 May 2021).

70. Colegiul Medicilor Stomatologi din Romania. Decizia Biroului Executiv National Nr. 16/3BExN/2020; CMSR: Bucharest, Romania, 2020.

71. Colegiul Medicilor Stomatologi din Romania. Registrul Special de Evidență. Available online: https://cmdr.ro/wp-content/ uploads/2020/05/2020.05.14-16.00-RSENISU.pdf (accessed on 13 July 2021).

72. Regulation (Eu) 2016/679 of the European Parliament and of the Council of 27 April 2016. Off. J. Eur. Union 2016, L 119, 1-88.

73. Yale, S.; Kumar, S.; Sharma, V. Current and Potential Use of WhatsApp in Oral Health Care-a Narrative Review. Int. J. Health Sci. Res. 2018, 8, 278-284.

74. Johnsen, J.-A.K.; Eggesvik, T.B.; Rørvik, T.H.; Hanssen, M.W.; Wynn, R.; Kummervold, P.E. Differences in Emotional and Pain-Related Language in Tweets About Dentists and Medical Doctors: Text Analysis of Twitter Content. JMIR Public Health Surveill 2019, 5, e10432. [CrossRef] 
75. Facebook MAU Worldwide. 2021. Available online: https://www.statista.com/statistics/264810/number-of-monthly-activefacebook-users-worldwide/ (accessed on 3 October 2021).

76. Briciu, V.-A.; Briciu, A. Social Media and Organizational Communication. In Encyclopedia of Organizational Knowledge, Administration, and Technology; IGI Global: Hershey, PA, USA, 2021; pp. 2609-2624. ISBN 978-1-79983-473-1.

77. Organisation for Economic Co-operation and Development; World Health Organization; World Bank Group. Delivering Quality Health Services: A Global Imperative for Universal Health Coverage; OECD Publishing: Paris, France, 2018; ISBN 978-92-64-30030-9.

78. Analyzing Conflicting Results in Rapid Point-of-Care COVID-19 Testing. 2020. Available online: https://dash.harvard.edu/ bitstream/handle/1/37364504/MICHAEL\%20MINA\%20-\%20HCPMSA\%2006.18.20_FINAL.pdf?sequence=1\&isAllowed=y (accessed on 11 April 2021).

79. FDI World Dental Federation. FDI Statement. Available online: https://www.fdiworlddental.org/sites/default/files/2020-11/ fdi_statement_who_en.pdf (accessed on 23 April 2021).

80. Centobelli, P.; Cerchione, R.; Vecchio, P.D.; Oropallo, E.; Secundo, G. Blockchain Technology for Bridging Trust, Traceability and Transparency in Circular Supply Chain. Inf. Manag. 2021, 103508. [CrossRef]

81. Doctorpreneurs-The Community for Medical Entrepreneurs. Available online: https://doctorpreneurs.com/ (accessed on 15 October 2021). 